\title{
DISEMINASI INFORMASI ADMINISTRASI DAN AKADEMIK MELALUI KATALOG UNIVERSITAS TERBUKA PADA MAHASISWA PROGRAM NON PENDIDIKAN DASAR DI UPBJJ-UT MATARAM
}

\author{
Windi Baskoro Prihandoyo
}

\begin{tabular}{l}
\hline INFO ARTIKEL \\
\hline Riwayat Artikel: \\
Diterima: $08-09-2016$ \\
Disetujui: 30-09-2016 \\
\hline Kata Kunci: \\
Effectiveness, \\
Dissemination, \\
Administration, \\
Academic, Catalogs
\end{tabular}

\begin{abstract}
ABSTRAK
Abstract: This study aims to identify and analyze the effectiveness of Administrative and Academic Information Dissemination through the Open University Catalog On Non Basic Education Program Student in UPBJJ-UT Mataram. The method used in this research is descriptive correlational survey. The results in this study is that there was a significant relationship between: 1) the characteristics of the respondents, the accessibility of information and intensity of communication with the effectiveness of administrative and academic information dissemination through the catalog of the Open University in UPBJJ-UT Mataram. 2) Each of the three independent variables: characteristics, accessibility of information and communication intensity Non Basic student in UT UPBJJ Mataram. 3) Use of the Open University catalog with the catalog of benefits for Non Basic student in UT UPBJJ Mataram.
\end{abstract}

\section{A. LATAR BELAKANG}

Universitas Terbuka (UT) menerapkan sistem belajar terbuka dan jarak jauh. Sistem Belajar Jarak Jauh (SBJJ) yang diterapkan UT menuntut mahasiswa belajar mandiri. Sistem ini menuntut mahasiswa untuk memiliki prakarsa atau inisiatif sendiri dalam mempelajari bahan ajar, mengerjakan tugas-tugas, memantapkan keterampilan, dan menerapkan pengalaman belajarnya di lapangan atau pekerjaan.

Informasi di UT merupakan hal yang sangat penting. Tertinggal satu informasi akan berakibat terhambatnya proses studi mahasiswa UT. Penyebaran informasi di UT memanfaatkan berbagai media, seperti internet, buku (katalog), telepon, telepon seluler, surat, VCD dan komunikasi tatap muka. Pentingnya informasi di UT mengharuskan mahasiswa kreatif dalam mencari atau menggali informasi akademik UT untuk menunjang studi di UT.

Untuk mengetahui apakah proses diseminasi informasi akademik melalui katalog UT pada mahasiswa Program Non Pendas di UPBJJ-UT Mataram ini efektif atau telah memenuhi kebutuhan dan harapan dari mahasiswa, maka dilakukan penelitian tentang Diseminasi Informasi Akademik Melalui Katalog Universitas Terbuka Pada Mahasiswa Program Non Pendidikan Dasar di UPBJJ-UT Mataram.

Rumusan permasalahan yang akan diteliti sebagai berikut: (1) Seberapa besar hubungan antara karakteristik petani sayuran, aksessibilitas informasi dan intensitas komunikasi dengan efektivitas diseminasi informasi di bidang pertanian melalui media telepon genggam di Kecamatan Pacet Kabupaten Cianjur Provinsi Jawa Barat?; (2) Seberapa besar hubungan antara ketiga peubah bebas: karaktersitik, aksesibilitas informasi, dan intensitas komunikasi petani sayuran di Kecamatan Pacet Kabupaten Cianjur Provinsi Jawa Barat?; dan (3) Seberapa besar hubungan antara penggunaan telepon genggam terhadap kelancaran dan peningkatan usaha tani petani sayuran di Kecamatan Pacet Kabupaten Cianjur Provinsi Jawa Barat?

Tujuan dari penelitian ini adalah 1) Menganalisis hubungan antara karakteristik petani sayuran, aksesibilitas informasi dan intensitas komunikasi dengan efektivitas diseminasi informasi di bidang pertanian; 2) Menganalisis hubungan antara ketiga peubah bebas: karaktersitik, aksesibilitas informasi, dan intensitas komunikasi petani sayuran; dan 3) Menganalisis hubungan antara penggunaan telepon genggam terhadap kelancaran dan peningkatan usaha tani petani sayuran.

Rumusan masalah dalam penelitian ini adalah: (1) Seberapa besar hubungan antara karakteristik mahasiswa program Non Pendidikan Dasar Universitas Terbuka, aksesibilitas informasi dan intensitas mahasiswa membaca katalog Universitas Terbuka dengan efektivitas diseminasi Akademik Melalui Katalog Universitas Terbuka Pada Mahasiswa Non Pendidikan Dasar Program Bidikmisi di UPBJJUT Mataram, (2) Seberapa besar hubungan antara ketiga peubah: karakteristik mahasiswa program Non Pendidikan Dasar Universitas Terbuka, aksesibilitas informasi dan intensitas mahasiswa membaca katalog 
Universitas Terbuka, dan (3) Seberapa besar hubungan antara penggunaan katalog Universitas Terbuka dengan manfaat membaca katalog.

Tujuan dari penelitian ini adalah (1) Menganalisis keeratan hubungan karakteristik mahasiswa program Non Pendidikan Dasar Universitas Terbuka, aksesibilitas informasi dan intensitas mahasiswa membaca katalog Universitas Terbuka dengan efektivitas diseminasi Akademik Melalui Katalog Universitas Terbuka Pada Mahasiswa Non Pendidikan Dasar Program Bidikmisi di UPBJJUT Mataram, (2) Menganalisis keeratan hubungan antara ketiga peubah: karakteristik mahasiswa program Non Pendidikan Dasar Universitas Terbuka, aksesibilitas informasi dan intensitas mahasiswa membaca katalog Universitas Terbuka, dan (3) Menganalisis keeratan hubungan antara penggunaan katalog Universitas Terbuka dengan manfaat membaca katalog.

Penelitian terdahulu tentang efektivitas diseminasi bisa dilihat pada Prihandoyo, Muljono, dan Susanto (2014) efektivitas diseminasi informasi pertanian melalui media telepon genggam pada petani sayuran di Kecamatan Pacet Kabupaten Cianjur, hasil penelitian menunjukkan bahwa penggunaan telepon genggam sebagai sarana/media diseminasi informasi pertanian di Kecamatan Kabupaten Cianjur sudah efektif dan memenuhi serta sesuai dengan harapan dari petani sayuran.

Hasil penelitian Soheh dan Walujo (2014) menggambarkan bahwa efektifitas Tabloid Komunika bagi pegawai dinilai sangat efektif dalam memberikan suatu informasi yang akan membuat adanya perubahan suatu sikap setelah mendapatkan informasi tersebut. Hasil penelitian mengenai efektifitas Tabloid Komunika sebagai media diseminasi informasi bagi pegawai Puslitbang Postel dan Puslitbang Aptel SKDI Badan Litbang SDM Depkominfo dikategorikan sangat setuju, setuju, tidak tahu, tidak setuju, sangat tidak setuju.

Penelitian Kamaruzaman (2009) tentang Desain Video Trainning yang Efektif dalam Diseminasi Informasi Teknologi Pertanian di Sulawesi Tenggara diperoleh hasil bahwa M-learning dari pemerintah kepada masyarakat kota Semarang memiliki potensi untuk diterapkan khususnya melalui SMS. Hal ini terkait dengan telah memasyarakatnya ponsel di kalangan warga Semarang yang dapat menerima informasi utama tanpa dibebani biaya. Dan dukungan kesiapan teknologi, infrastruktur dari provider maupun pemerintah dalam penerapan program M-learning.

Sedangkan hasil penelitian Maksum, Buldansyah, dan Prawati (2008) menggambarkan efektivitas layanan informasi digital cenderung ditentukan oleh tingkat kebutuhan pengguna dan ketersediaan informasi yang akurat, serta kecepatan dan ketepatan dalam pelayanan yang terutama ditentukan oleh ketersediaan fasilitas akses. Terungkap pula bahwa pengguna kelompok mahasiswa yang datang ke perpustakaan lebih berminat terhadap informasi yang berupa artikel lengkap dari pada yang berbentuk bibliografi.

Manfaat penelitian ini terbagi menjadi dua, yaitu: secara akademik Secara akademik diharapkan hasil penelitian dapat memberikan kontribusi dalam penelitian dan pengembangan keilmuan di bidang komunikasi, khususnya di bidang diseminasi informasi melalui berbagai media informasi dan secara praktis diharapkan hasil penelitian dapat memberikan masukan bagi UPBJJ-UT Mataram dalam upaya diseminasi informasi baik administrasi maupun akademik kepada mahasiswa yang berada dalam wilayah kerjanya.

\section{B. METODE PENELITIAN}

Metode penelitian yang digunakan dalam penelitian ini adalah metode penelitian survei deskriptif korelasional. Penelitian ini dilakukan di UPBJJ-UT Mataram pada bulan Agustus - September 2015. Populasi dalam penelitian ini adalah mahasiswa program Non Pendas di UPBJJ-UT Mataram sebanyak 424 orang dengan kriteria : (1) Mahasiswa Program Non Pendas yang ada di UPBJJ UT Mataram, dan (2) Memiliki katalog Program Non Pendas. Dari populasi jumlah mahasiswa Program Non Pendas yang ada di UPBJJ UT Mataram sebanyak 424 orang diambil sampel sebanyak $20 \%$ dari populasi, yaitu sebanyak 85 orang. Selanjutnya pengambilan sampel yang dilakukan dengan cara acak sederhana. Berdasarkan hasil analisis menggunakan SPSS versi 20.0 terhadap seluruh isntrumen kepada 15 orang responden, maka diperoleh hasil 0.695. Ini berarti instrumen yang akan digunakan sudah reliabel. Data yang didapat kemudian dianalisis menggunakan uji korelasi Rank Spearman untuk melihat kereatan hubungan variabel yang diteli. Kemudian disajikan dalam bentuka tabel rataan skor dan tabel frkuensi.

\section{HASIL DAN PEMBAHASAN}

1. HASIL

\section{a) Hubungan Karakteristik Mahasiswa Program Non Pendas, Aksesibilitas Informasi Dan Intensitas Komunikasi Dengan Efektivitas Diseminasi Informasi}

Hipotesis penelitian ini adalah terdapat hubungan nyata dan positif antara peubah karakteristik mahasiswa program Non Pendas, aksesibilitas informasi dan intesitas komunikasi dengan efektivitas diseminasi informasi akademik melalui Katalog Universitas Terbuka di UPBJJ-UT Mataram. Untuk mengetahui besaran hubungan antara kedua peubah dilakukan pengujian statistik dengan menggunakan uji korelasi Rank Spearman pada taraf $\alpha=0,05$ dengan menggunakan program SPSS 20.0 for windows.

b) Hubungan Karakteristik Mahasiswa
Program Non Pendas dengan Efektivitas
Diseminasi Informasi Akademik Melalui
Katalog Universitas Terbuka Hubungan antara karakteristik Mahasiswa
Non Pendas dengan Efektivitas Program Non Pendas dengan Efektivitas
Diseminasi Informasi Akademik Melalui Katalog Universitas Terbuka dapat dilihat pada Tabel 1 berikut ini. 
Tabel 1 Nilai uji hubungan antara karakteristik Mahasiswa Program Non Pendas dengan Efektivitas Diseminasi Informasi

Akademik Melalui Katalog Universitas Tahun 2015

\begin{tabular}{|c|c|c|c|c|c|}
\hline \multirow[b]{2}{*}{$\begin{array}{l}\text { Efektivitas } \\
\text { Diseminasi } \\
\text { Informasi }\end{array}$} & \multicolumn{5}{|c|}{ Karakteristik Mahasiswa Program Non Pendas } \\
\hline & $\begin{array}{l}\text { Umur } \\
\text { mhs }\end{array}$ & $\begin{array}{l}\text { Kepemilikan } \\
\text { TIK }\end{array}$ & $\begin{array}{l}\text { Penggunaan } \\
\text { Katalog }\end{array}$ & $\begin{array}{l}\text { Jumlah } \\
\text { Informasi }\end{array}$ & $\begin{array}{l}\text { Aktivitas mhs } \\
\text { dlm melakukan } \\
\text { kontak dengan } \\
\text { berbagai } \\
\text { sumber } \\
\text { informasi }\end{array}$ \\
\hline $\begin{array}{l}\text { kinerja } \\
\text { katalog } \\
\text { sebagai } \\
\text { sumber } \\
\text { informasi }\end{array}$ & $.222^{*}$ & $.284^{*}$ & $-.266^{*}$ & $.244^{*}$ & .076 \\
\hline $\begin{array}{l}\text { Ketersediaan } \\
\text { informasi } \\
\text { kesesuaian }\end{array}$ & .213 & 213 & -.099 & $.233^{*}$ & -.075 \\
\hline $\begin{array}{l}\text { informasi } \\
\text { yang dicari }\end{array}$ & .088 & .073 & 0.96 & .171 & -.204 \\
\hline $\begin{array}{l}\text { Kepuasan } \\
\text { terhadap } \\
\text { hasil yang } \\
\text { dicapai }\end{array}$ & $.305^{* *}$ & .041 & -.105 & .142 & .030 \\
\hline $\begin{array}{l}\text { Kepuasan } \\
\text { terhadap } \\
\text { penggunaan } \\
\text { katalog } \\
\text { Universitas } \\
\text { Terbuka }\end{array}$ & .137 & .098 & -.108 & $.230^{*}$ & -.039 \\
\hline
\end{tabular}

**. Hubungan sangat nyata pada $a=\leq 0.01(2-$ tailed).

*. Hubungan sangat nyata pada $\alpha=\leq 0.05$ (2-tailed).

Adanya hubungan sangat nyata dan positif antara umur mahasiswa dan kepemilikan TIK dengan kinerja katalog sebagai sumber informasi pada pada $a=<0.05$. Terdapat hubungan sangat nyata dan positif antara jumlah informasi dengan Ketersediaan informasi dan kepuasan terhadap penggunaan katalog Universitas Terbuka pada $a=<0.05$. Sedangkan umur mahasiswa memiliki hubungan nyata dan positif pada $\alpha=<0.01$.

Sedangkan adanya hubungan yang negatif antara penggunaan katalog Universitas Terbuka dengan kepuasan terhadap hasil yang dicapai dan kepuasan terhadap penggunaan katalog Universitas Terbuka dapat dimengerti karena mahasiswa tidak semua informasi dapat diperoleh melalui katalog Universitas Terbuka, khususnya

\begin{tabular}{|c|c|c|c|c|}
\hline \multirow{2}{*}{$\begin{array}{c}\text { Efektivitas } \\
\text { Diseminasi } \\
\text { Informasi } \\
\end{array}$} & \multicolumn{4}{|c|}{ Aksesibilitas Informasi } \\
\hline & $\begin{array}{c}\text { Jenis } \\
\text { informasi }\end{array}$ & $\begin{array}{c}\text { Sumber } \\
\text { informasi }\end{array}$ & $\begin{array}{c}\text { Jumlah } \\
\text { Komunikasi }\end{array}$ & $\begin{array}{c}\text { Waktu mencari } \\
\text { informasi }\end{array}$ \\
\hline kinerja katalog & & & & \\
\hline $\begin{array}{l}\text { sebagai sumber } \\
\text { informasi }\end{array}$ & -.020 & $.279^{*}$ & .175 & .190 \\
\hline $\begin{array}{l}\text { Ketersediaan } \\
\text { informasi }\end{array}$ & -.024 & $.274^{*}$ & .115 & .076 \\
\hline kesesuaian & & & & \\
\hline $\begin{array}{l}\text { informasi yang } \\
\text { dicari }\end{array}$ & -.059 & .111 & .111 & -.018 \\
\hline $\begin{array}{l}\text { Kepuasan terhadap } \\
\text { hasil yang dicapai }\end{array}$ & -.179 & .044 & .157 & .189 \\
\hline $\begin{array}{l}\text { Kepuasan terhadap } \\
\text { penggunaan katalog } \\
\text { Universitas Terbuka }\end{array}$ & -.038 & $.261^{*}$ & .102 & .122 \\
\hline
\end{tabular}

*. Hubungan nyata pada $\alpha=\leq 0.05$ (2tailed).

Sumber informasi berhubungan sangat nyata dan positif dengan kinerja katalog sebagai sumber informasi tentang registrasi, tutorial tatap muka, ujian akhir semester, nilai, perubahan kode mata kuliah, yudisium dan wisuda atau Upacara Penyerahan Ijazah.

c) Hubungan Aksesibilitas Informasi Dengan Efektivitas Diseminasi Informasi Akademik Melalui Katalog Universitas Terbuka

Hubungan antara aksesibilitas informasi dengan Efektivitas Diseminasi Informasi Akademik Melalui Katalog Universitas Terbuka dapat dilihat pada Tabel 2 berikut ini.

Tabel 2 Nilai uji hubungan Aksesibiltas Informasi dengan Efektivitas Diseminasi Informasi Akademik Melalui Katalog Universitas Tahun 2015 


\section{d) Hubungan Intensitas Komunikasi Dengan Efektivitas Diseminasi Informasi Akademik Melalui Katalog Universitas Terbuka}

Intensitas komunikasi merupakan aktifitas responden dalam berinteraksi dengan pihak lain, baik secara interpersonal, kelompok ataupun massa yang diukur melalui frekuensi interaktif dan frekuensi diskusi. Intensitas komunikasi yang dilakukan responden dalam mencari informasi yang dibutuhkan memiliki hubungan yang sangat nyata dengan efektivitas diseminasi informasi. Hubungan antara intensitas komunikasi dengan Efektivitas Diseminasi Informasi Akademik Melalui Katalog Universitas Terbuka dapat dilihat pada Tabel 3 .

Tabel 3 Nilai uji hubungan Intensitas Komunikasi dengan Efektivitas Diseminasi Informasi Akademik Melalui Katalog Universitas Tahun 2015

\begin{tabular}{|c|c|c|}
\hline \multirow{2}{*}{$\begin{array}{l}\text { Efektivitas Diseminasi } \\
\text { Informasi }\end{array}$} & \multicolumn{2}{|c|}{ Intensitas Komunikasi } \\
\hline & $\begin{array}{l}\text { Intensitas } \\
\text { Komunikasi }\end{array}$ & $\begin{array}{c}\text { Diskusi } \\
\text { kelompok }\end{array}$ \\
\hline $\begin{array}{l}\text { kinerja katalog sebagai } \\
\text { sumber informasi }\end{array}$ & .069 & -.056 \\
\hline Ketersediaan informasi & .112 & .030 \\
\hline $\begin{array}{l}\text { kesesuaian } \\
\text { yang dicari }\end{array}$ & -.020 & -.098 \\
\hline $\begin{array}{l}\text { Kepuasan terhadap hasil } \\
\text { yang dicapai }\end{array}$ & .012 & -.057 \\
\hline $\begin{array}{lr}\text { Kepuasan } & \text { terhadap } \\
\text { penggunaan } & \text { katalog } \\
\text { Universitas Terbuka }\end{array}$ & .000 & .011 \\
\hline
\end{tabular}

Adanya hubungan positif antara intensitas komunikasi dengan kinerja katalog sebagai sumber informasi, ketersediaan informasi, kepuasan terhadap hasil yang dicapai dan kepuasan terhadap penggunaan katalog Universitas Terbuka. Dan hubungan positif antara diskusi kelompok dengan ketersediaan informasi dan kepuasan terhadap penggunaan katalog Universitas Terbuka. Sedangkan hubungan negatif terdapat antara intensitas komunikasi dengan kesesuaian informasi yang dicari. Hubungan negatif juga terdapat ada diskusi kelompok dengan dengan kinerja katalog sebagai sumber informasi, kesesuaian informasi yang dicari dan kepuasan terhadap penggunaan katalog Universitas Terbuka. Ini menunjukkan bahwa semakin tinggi kinerja layanan sumber informasi dan ketersediaan informasi, maka akan semakin tinggi intensitas komunikasi antara responden dengan sumber informasi. Hal ini terjadi karena responden merasa puas terhadap hasil yang dicapai dan merasa puas terhadap penggunaan katalog Universitas Terbuka.

Berdasarkan hasil penelitian dapat disimpulkan bahwa penggunaan katalog sebagai media diseminasi informasi adinistrasi dan akademik pada mahasiswa program Non Pendas di UPBJJ-UT Mataram relatif sangat efektif. Ini berarti hipotesis pertama dalam penelitian ini dapat diterima.

e) Hubungan Ketiga Peubah: Karaktersitik, Aksesibilitas Informasi, Dan Intensitas Komunikasi Mahasiswa Program Non Pendas

Hipotesis kedua dalam penelitian ini adalah Terdapat hubungan nyata positif antara masingmasing dari ketiga Peubah bebas: karakteristik, aksesibilitas informasi dan intensitas komunikasi mahasiswa program Non Pendas UPBJJ-UT Mataram.

1. Hubungan antara karakteristik mahasiswa program Non Pendas dengan aksesibilitas informasi

Tabel 4 Nilai uji hubungan antara karakteristik mahasiswa program Non Pendas dengan Aksesibilitas Informasi di UPBJJ-UT Mataram Tahun 2015

\begin{tabular}{|c|c|c|c|c|c|}
\hline & & & Aksesi & tas informasi & \\
\hline & $\begin{array}{l}\text { Karakteristik } \\
\text { mahasiswa }\end{array}$ & $\begin{array}{l}\text { Jenis } \\
\text { informasi }\end{array}$ & $\begin{array}{l}\text { Sumber } \\
\text { informasi }\end{array}$ & $\begin{array}{c}\text { Jumlah } \\
\text { Komunikasi }\end{array}$ & $\begin{array}{c}\text { Waktu } \\
\text { mencari } \\
\text { informasi }\end{array}$ \\
\hline & Umur mhs & -.016 & .210 & .071 & .005 \\
\hline & $\begin{array}{l}\text { Kepemilikan } \\
\text { TIK }\end{array}$ & .022 & $.431^{* *}$ & .044 & -.021 \\
\hline & $\begin{array}{l}\text { Penggunaan } \\
\text { Katalog }\end{array}$ & -.144 & -.143 & -.043 & -.027 \\
\hline & $\begin{array}{l}\text { Jumlah } \\
\text { Informasi }\end{array}$ & .135 & $.351^{* *}$ & $.276^{*}$ & .017 \\
\hline & $\begin{array}{l}\text { Aktivitas mhs } \\
\text { dlm melakukan } \\
\text { kontak dengan } \\
\text { berbagai } \\
\text { sumber } \\
\text { informasi }\end{array}$ & .013 & .011 & $545^{* *}$ & $.216^{*}$ \\
\hline $\begin{array}{l}* * \text { Hubungan } \\
\text { (2-tailed). }\end{array}$ & sangat nyata pac & $\alpha=\leq 0$. & & $\begin{array}{l}\text { Hubungan ny } \\
\text { ailed). }\end{array}$ & pada a \\
\hline
\end{tabular}


Hasil penelitian menunjukkan terdapat hubungan sangat nyata dan positif antara karakteristik mahasiswa program Non Pendas dengan aksesibilitas informasi. Hubungan sangat nyata dan positif ini antara kepemilikan teknologi informasi komunikasi dengan sumber informasi pada $\alpha=\leq$ 0.01. Hubungan sangat nyata dan positif juga terjadi antara jumlah informasi dengan sumber informasi pada $\alpha=\leq 0.01$. Adanya hubungan sangat nyata dan positif antara aktivitas mahasiswa dalam melakukan kontak dengan berbagai sumber informasi dengan jumlah komunikasi pada $\alpha=\leq 0.01$. Fakta ini menunjukkan bahwa semakin banyak responden mengetahui berbagai sumber informasi yang dapat dihubungi, maka akan semakin tinggi jumlah komunikasi yang dilakukan oleh responden dengan sumber informasi.

2. Hubungan antara karakteristik mahasiswa program Non Pendas dengan intensitas komunikasi

Tabel 5 Nilai uji hubungan antara Karakteritik Mahasiswa program Non Pendas dengan intensitas komunikasi di UPBJJ-UT Mataram Tahun 2015

\begin{tabular}{|l|c|c|}
\hline \multirow{2}{*}{$\begin{array}{l}\text { Karakteristik mahasiswa program } \\
\text { Non Pendas }\end{array}$} & $\begin{array}{l}\text { Intensitas } \\
\text { interaktif }\end{array}$ & Frekuensi diskusi \\
\cline { 2 - 3 } & .150 & .008 \\
\hline Umur mhs & .056 & .071 \\
\hline Kepemilikan TIK & -.064 & .038 \\
\hline Penggunaan Katalog & $.219^{*}$ & -.061 \\
\hline Jumlah Informasi & $.387^{* *}$ & $.344^{* *}$ \\
\hline $\begin{array}{l}\text { Aktivitas mhs dlm melakukan } \\
\text { kontak dengan berbagai sumber } \\
\text { informasi }\end{array}$ & & \\
\hline
\end{tabular}

**. Hubungan sangat nyata pada $\alpha=\leq 0.01$ (2-tailed).

Hasil analisis pada Tabel 5 menunjukkan bahwa secara umum terdapat hubungan nyata positif antara karakteristik mahasiswa program Non Pendas dengan intensitas komunikasi. Terdapat hubungan sangat nyata dan positif antara aktivitas mahasiswa dalam melakukan kontak dengan berbagai sumber informasi dengan intensitas interaktif dan frekuensi diskusi pada $\alpha$ $=\leq$ 0.01. Hal ini menunjukkan bahwa semakin banyak responden mengetahui berbagai sumber informasi yang dapat dihubungi,, maka akan semakin tinggi tingkat intensitas interaktif antara responden dengan sumber informasi dan semakin tinggi frekuensi diskusi yang dilakukan oleh responden, baik antara sesama mahasiswa program Non Pendas maupun dengan sumber informasi lainnya.

3. Hubungan antara aksesibilitas informasi dengan intensitas komunikasi

Tabel 6 Nilai uji hubungan antara Aksesibilitas Informasi dengan Intensitas Komunikasi di UPBJJ-UT Mataram Tahun 2015

\begin{tabular}{|c|c|c|}
\hline \multirow{2}{*}{$\begin{array}{l}\text { Aksesibilitas } \\
\text { informasi }\end{array}$} & \multicolumn{2}{|c|}{ Intensitas komunikasi } \\
\hline & Intensitas interaktif & Frekuensi diskusi \\
\hline Jenis informasi & -.043 & -.108 \\
\hline Sumber informasi & $.264^{*}$ & -.036 \\
\hline Jumlah Komunikasi & $.589^{* *}$ & $.296^{* *}$ \\
\hline $\begin{array}{l}\text { Waktu mencari } \\
\text { informasi }\end{array}$ & .177 & .073 \\
\hline
\end{tabular}

**. Hubungan sangat nyata pada $\alpha=\leq 0.01$ (2-tailed).

*. Hubungan nyata pada $\alpha=\leq 0.05$ (2tailed).

Hasil penelitian pada Tabel 6 menunjukkan bahwa terdapat hubungan nyata positif antara aksesibilitas informasi dengan intensitas komunikasi. Hubungan sangat nyata dan positif ini terdapat pada hubungan antara intensitas interaktif dengan sumber informasi dan waktu mencari informasi pada $\alpha<0,05$. Hubungan sangat nyata dan positif juga terjadi antara jumlah komunikasi dengan intensitas interaktif pada $\alpha<0,01$. Dengan demikian dapat disimpulkan bahwa semakin banyak sumber informasi yang diketahui oleh responden, maka akan semakin tinggi intensitas interatif. Semakin tinggi tingkat interaktif responden, maka akan semakin banyak jumlah komunikasi dan waktu yang dibutuhkan oleh responden untuk mencari informasi yang dibutuhkan.

Tabel 25 juga menunjukkan hubungan sangat nyata dan positif antara frekuensi diskusi dengan jumlah komunikasi pada $\alpha<0,01$. Hal ini menunjukkan bahwa semakin tinggi frekuensi diskusi yang dilakukan oleh responden, maka akan semakin banyak jumlah komunikasi yang dilakukan oleh responden.

Hasil penelitian menunjukkan bahwa terdapat hubungan nyata positif antara antara masing-masing dari ketiga Peubah bebas. Hal ini berarti bahwa terdapat hubungan keeratan yang kuat antara karakteristik mahasiswa program Non Pendas dengan aksesibilitas informasi, karakteristik mahasiswa program Non Pendas dengan intensitas komunikasi dan aksesibilitas informasi dengan intensitas 
komunikasi mahasiswa program Non Pendas di UPBJJ-UT Mataram. Dengan demikian dapat disimpulkan bahwa hipotesis kedua dalam penelitian ini dapat diterima.

\section{f) Hubungan Penggunaan Katalog Universitas Terbuka dengan Manfaat Penggunaan Katalog Universitas Terbuka}

Hipotesis ketiga dalam penelitian ini adalah Terdapat hubungan nyata dan positif antara penggunaan Katalog Universitas Terbuka terhadap

\begin{tabular}{ll}
\hline \multirow{2}{*}{ Peubah tak bebas } & Peubah bebas \\
\cline { 2 - 2 } & $\begin{array}{l}\text { Penggunaan Katalog Universitas Terbuka untuk } \\
\text { mencari informasi }\end{array}$ \\
\hline Manfaat Katalog Universitas Terbuka & .136
\end{tabular}

Hasil tabel tersebut menunjukkan bahwa terdapat hubungan positif antara penggunaan Katalog Universitas Terbuka sebagai media untuk mencari informasi yang dibutuhkan dengan manfaat penggunaan Katalog Universitas Terbuka. Hal ini menunjukkan bahwa penggunaan Katalog Universitas Terbuka untuk mencari informasi memiliki manfaat bagi responden selama menempuh studi di Universitas Terbuka. Diindikasikan bahwa responden sudah maksimal memanfaatkan Katalog Universitas Terbuka untuk mencari informasi yang dibutuhkan.

\section{SIMPULAN DAN SARAN \\ 1. SIMPULAN}

a) Secara umum karakteristik responden, aksesibilitas informasi dan intensitas komunikasi berhubungan nyata dengan efektivitas diseminasi informasi administrasi dan akademik melalui katalog Universitas Terbuka di UPBJJ-UT Mataram.

b) Secara umum terdapat hubungan yang nyata dan positif antara masing-masing dari ketiga Peubah bebas: karakteristik, aksesibilitas informasi dan intensitas komunikasi mahasiswa program Non Pendas di UPBJJ-UT Mataram.

c) Terdapat hubungan positif antara penggunaan katalog Universitas Terbuka dengan manfaat katalog Universitas Terbuka bagi mahasiswa program Non Pendas di UPBJJ-UT Mataram.

d) Penggunaan katalog Universitas Terbuka sebagai media diseminasi informasi administrasi dan akademik di UPBJJ-UT Mataram sudah efektif dan memenuhi serta sesuai dengan kebutuhan mahasiswa program Non Pendas

\section{SARAN}

a) Perlu adanya sosialisasi dari pihak UPBJJ-UT Mataram tentang keberadaan katalog Universitas Terbuka online kepada mahasiswa program Non Pendas, sehingga mahasiswa dapat mencari informasi yang terbaru yang tidak terdapat dalam katalog Universitas Terbuka versi cetak. selama menempuh studi di Universitas Terbuka. pemenuhan kebutuhan informasi administrasi dan akademik mahasiswa program Non Pendas di UPBJJUT Mataram. Hubungan antara penggunaan Katalog Universitas Terbuka dengan manfaat penggunaan Katalog Universitas Terbuka mahasiswa program Non Pendas di UPBJJ-UT Mataram dapat dilihat pada Tabel 26 berikut ini.

Tabel 26 Nilai uji hubungan Penggunaan Katalog Universitas Terbuka dengan manfaat penggunaan Katalog Universitas Terbuka di UPBJJ-UT Mataram Tahun 2015 encari informasi

b) Perlu dibentuk jaringan komunikasi antar mahasiswa program Non Pendas dan penunjukan pembimbing akademik bagi mahasiswa program Non Pendas di UPBJJ-UT Mataram untuk membantu mahasiswa selama menempuh studi di Universitas Terbuka.

\section{DAFTAR RUJUKAN}

Kamaruzaman I. 2009. Desain Video Trainning yang Efektif dalam Diseminasi Informasi Teknologi Pertanian di Sulawesi Tenggara. Kendari (ID): Universitas Haluoleo.

Maksum, Buldansyah DL, Prawati B. 2008. Aksesibilitas informasi, Intensitas Komunikasi, dan Efektivitas Layanan Informasi Digital. Bogor (ID): Pusat Perpustakaan dan Penyebaran Teknologi Pertanian. Jurnal Perpustakaan Pertanian. Vol. 17, Nomor 2, 2008.

Prihandoyo, W.B., Muljono, P., dan Susanto, D. 2014. Effectiveness of Agricultural Information Dissemination through Media Mobile Phone on Vegetable Farmers in the District Pacet, Cianjur Regency. Asian Journal of Humanities and Social Sciences (AJHSS) Volume 2-Issue.

Soheh, A. dan Walujo, K.W. 2014. Efektivitas Tabloid Komunika Sebagai Media Diseminasi Informasi Bagi Pegawai Puslitbang. Universitas Esa Unggul http://www.esaunggul.ac.id 